\title{
Low-Level Laser Therapy (LLLT) on Soft Tissue Healing: A Case Report with Literature Review
}

\author{
Islam $\mathrm{MN}^{1}$, Zakaria $\mathrm{GA}^{2}$, Sirazee $\mathrm{FH}^{3}$, Debenath $\mathrm{PC}^{4}$, Shamimuzzaman $\mathrm{K}^{5}$, Akhter $\mathrm{SMQ}^{6}$, Khan $\mathrm{AU}^{7}$, \\ Islam $\mathrm{SS}^{8}$
}

\begin{abstract}
Variety of skin wounds are difficult to treat. Cutaneous lesions are representing the dilemma due to high morbidity. To treat these lesions low-level laser therapy (LLLT) is currently available. Experimental in vitro and in vivo studies have been under development. LLLT is an effective method to modulate tissue repair. In this case report LLLT was applied to a women presenting with wound healing and the result was excellent. [J Shaheed Suhrawardy Med Coll, 2013;5(2):117-121]
\end{abstract}

Keywords: LLLT, bio-stimulation, soft tissue, wound healing

Received: December 2012; Revised: March 2013; Accepted: May 2013

\section{Introduction}

Allied health professionals regularly care for a variety of skin wounds, such as abrasions, turf burns, surgical incisions, and ulcerations, which are perhaps the most difficult to treat ${ }^{1}$. At present, cutaneous lesions represent a dilemma of global proportions and instigate great clinical interest because of the high morbidity associated with changes in the normal healing process ${ }^{2-6}$. Among the clinical aspects involving this issue, tissue repair time was emphasized in an effort to make the process quicker and more harmonious, reduce possible complications in lesion resolution $^{7-13}$ and allow an adequate choice of therapy ${ }^{14-20}$. To do this, familiarity with the pathogenesis of tissue healing is necessary ${ }^{21-24}$ as well as an understanding of the factors affecting the process and the role each one plays in its progress always seeking a clinical treatment that optimizes skin lesion care ${ }^{25-31}$. Among the methods currently available, low-level laser therapy (LLLT) stands out.

From acute wound management to augmentation of scar tissue remodeling, the clinician seeks to optimize wound care to promote healing. Experimental in vitro and in vivo studies have been under development since the 1960s, and in the early 1990s, LLLT was approved by the Food and Drug Administration (FDA) as an important method for treating healing processes ${ }^{2-4}$. Recent results of a study demonstrated that LLLT is an effective method to modulate tissue repair, thus significantly contributing to a faster and more organized healing process ${ }^{5}$. Nevertheless, in spite of the large number of studies involving this technique and its wide use in clinical practice, the principles of its action in cells and tissues are still not well understood. In this case report excellent wound heeling was resulfed in women reated LLLT

1. Dr. Md. Nazrul Islam, Resident Surgeon, Department of Orthopaedics \& Traumatology, Shaheed Suhrawardy Medical College Hospital, Dhaka

2. Prof. Golam Abu Zakaria, Department of Medical Radiation Physics, Kreiskrankenhaus Gummersbach, Teaching Hospital of the University of Cologne, Germany

3. Prof. F. H. Sirazee, Assistant Professor, Department of Orthopedic and Traumatology, Shaheed Suhrawardy Medical College Hospital, Dhaka

4. Dr. Paritosh Chandra Debenath, Associate Professor, Department of Orthopedic and Traumatology, Shaheed Suhrawardy Medical College Hospital, Dhaka

5. Dr. Kazi Shamimuzzaman, Assistant Professor, Department of Orthopedic and Traumatology, Shaheed Suhrawardy Medical College Hospital, Dhaka

6. Dr. SM Quamrul Akhter, Assistant Professor, Department of Surgery, Shaheed Suhrawardy Medical College, Dhaka

7. Dr. Ashraf Uddin Khan, Assistant Professor, Department of Radiology \& Imaging, Shaheed Suhrawardy Medical College, Dhaka

8. Dr. Sayed Shaheedul Islam, Assistant Professor, National Institute of Traumatology and Rehabilitation, Dhaka

\section{Correspondence}

Dr. Md. Nazrul Islam, Resident Surgeon, Department of Orthopedic and Traumatology \& In-charge, Biomedical Engeneering Department, Shaheed

Suhrawardy Medical College \& Hospital. Dhaka-1207, Bangladesh; Email: abbirr@gmail.com; Cell no.: +8801196133078

Contributions by authors: MNI, GAZ, FHS, PCD and KS were involved in the treatment as well proper management of the patient. MNI, SMQA, AUK, MMR \& SSI prepared the manuscript and revised the paper. 


\section{Case Report}

A 78 years old lady suffering from spastic neurological disorder was presented with the history of recurrent multiple large as well as small wound in the back which were approximately $1-2 \mathrm{~cm}$ deep and $6-8 \mathrm{~cm}$ in diameter with inflammation and profuse purulent discharging infection and was referred to a tertiary hospital in Dhaka after more than 6 months of local management with non-healing chronic open wound. At the time of admission, patient's vital signs were revealed normal. On general examination the patient was bedridden for years and all the system revealed normal except musculoskeletal and nervous system, which showed spastic muscular disorder and Parkinson disease. The wound was surrounded by large ulcerative skin lesion almost confluent with the spine. The surrounding areas of the lesion revealed slough and blackish necrotic debris. The total wound area covered about 6 by 8 inches (Figure 1). Investigations revealed low hemoglobin level $(10.7 \mathrm{~g} / \mathrm{dL})$; total leukocyte count was normal (4700 cells/cu mm); ESR was within normal limit $(16 \mathrm{~mm})$ with adequate platelets count $(210000 / \mathrm{cu} \mathrm{mm})$. Peripheral blood film revealed microcytic hypochromic anaemia. Liver and Kidney profiles were revealed normal limit. Urine microscopy and cultures were positive repeatedly. Blood culture had given no growth of pathogenic bacteria. Chest X-ray and spine were showed severe osteoporotic change. ECG were found old myocardial infraction. Echocardiography was showed mild left ventricular hypertrophy. Pus culture and sensitivity was performed at weekly intervals which yielded Pseudomonas species initially. Subsequent cultures were showed Staphylococcus aureus and Escherichia coli species which were supposed to be from contamination with urine. Appropriate antibiotics were given time to time throughout the hospital stay including intravenous ciprofloxacin (100 $\mathrm{mg} / \mathrm{kg} /$ day) and amikacin $(15 \mathrm{mg} / \mathrm{kg} /$ day) for 15 days. Antibiotics were subsequently changed both for wound and urine infection, to netilmycin $(6 \mathrm{mg} / \mathrm{kg} /$ day for 7 days $)$, cefotaxime $(100 \mathrm{mg} / \mathrm{kg} /$ day for 10 days $)$, kenamycin $(500$ mg 12 hourly for 7 days) and Clindamycin (300mg 12 hourly for 10 days duration). Alternate day cleaning and dressing of the wound was done with Betadine, E-usol and Hexisol.

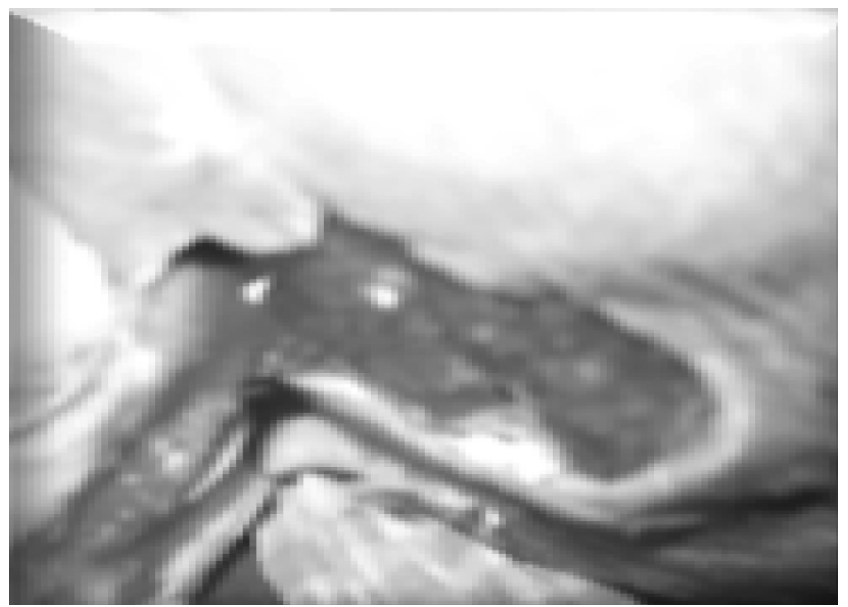

Figure 1: Before LLLT Therapy

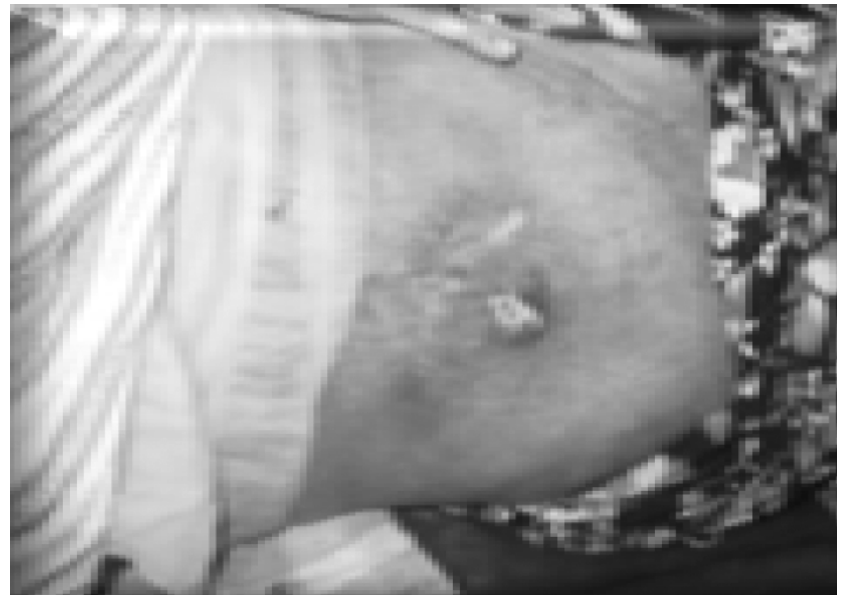

Figure 2: After LLLT Therapy

Regarding the irradiance parameters the LED apparatus was from BioLux MD; the beam source (Incoherent- GaAl-As); irradiance dose was $4-8 \mathrm{~J} / \mathrm{cm} 2 / \mathrm{min}$; irradiance time was 1-2 minutes; the mode was continuous wave; wavelengths was used in $660 \mathrm{~nm}$; total session was 35 . The parameters which have been found to be most effective are in the range of $90 \mathrm{sec} / \mathrm{cm} 2$ of open wound surface, with the laser beam set at a pulsed rate of $40-80$ pulses per second (PPS), depending upon the chronicity of the lesion. The more the chronic lesion, the slower the pulse rate is suggested. The optimum distance from probe tip to target surface was $1-4 \mathrm{~mm}$. Probe motion during lasing was a slow, circling movement over each square centimeter of open lesion, timed to permit the suggested dosages. As the lesion was large (4-6 cm in diameter), a change in technique was adopted which involves a slow, traversing of the perimeter of the lesion, allowing approximately $90 \mathrm{sec}$ per linear centimeter of the perimeter, at the suggested distances $(1-4 \mathrm{~cm})$. This technique apparently provides sufficient exposure to the laser beam to stimulate healing effectively, compared with non-treated areas and previously experienced wound management of a similar nature. Low energy Ga-Al laser provides infrared rays in the wave length of around $660 \mathrm{~nm}$ by continuous mode. An average power of 5-8 $\mathrm{mw}$ was provided through a fiber optic delivery system around the wound margin for about 8$10 \mathrm{~min}$ at each point at a distance of one $\mathrm{cm}$. Since the center of the ulcer was deep, it was decided to give laser therapy concentrating maximum irradiance there (Fig. 1). At the end of 2nd week there was an improvement in laser irradiated side with respect to ulcer size and wound margin and there was serous discharge after eight exposures (Table I). Surgical debridement was done 2 times: at 3 rd \& 5th week and finally secondary closure given at the end of 8th week, within in the treatment period (two and half months). A healthy granulation tissue appeared by 6-7th week. Fig. 6/7 reveals the post laser therapy ulcer on 6-7th week. At this stage, the center of the ulcer was still unhealthy and significant signs of healing. It was decided to irradiate the center of ulcer also with maximum permitted irradiance 
dose. At the end of 8th week the wound looked pretty healthy, we decided to do secondary closure instead of skin grafting, as because of old age, we could mobiles the wound adjacent skin without tension and closed the wound by four point suture. And next two weeks we observed the wound surface with a keen observation, and continued to two days interval laser therapy ( Total treatment 25), and medications properly. Enhancement of healing processes with open lesions is described. The effective parameters were determined to be a pulsed beam at 40-80 PPS, administered at a target distance of $4 \mathrm{~mm}$, for $90 \mathrm{sec} / \mathrm{cm} 2$ of open lesion surface. In addition, lasing along the perimeter of the larger wound was indicated to overcome the diminished penetration of the laser beam through the hardened eschar overlaying the lesion. No untoward reactions or side effects were reported by the patient.

Chronology of management and improvement: At the 5th day of admission in hospital, conservative treatment was simultaneously started and $\mathrm{He}-\mathrm{Ne}$ laser therapy. After wound cleaning, standardized digital photos were recorded weekly. At the end of 2nd week of treatment, the outlook of the wound was improved and the signs of increased vascularity in the surrounding area were noted. However, serous discharge was continued. At the end of $3 \mathrm{rd}$ week of treatment, wound debridement was performed and was continued alternate day dressing as well as laser therapy. At the 4th week of treatment, the wound was continued to care by alternate day dressing and medications and noticed formation of granulation tissue at the margin of the wound. At the end of 5th week of treatment, the center of the wound was debrided with care so that the adjacent healthy tissue could be preserved. At the end of 6th week of treatment, marked improvement was observed in the wound and at the same time signs of vascular marking noted at the wound margin. At the 7th week of treatment, general condition of the wound was noticed as healthy. The signs of healthy granulation tissue were noticed in all over the wound and dressing was continued to two days interval. No discharge was noted. At the end of 8th week of treatment, surgical toileting was done and secondary closure of the wound was performed; furthermore conservative was continued and laser therapy was given twice weekly until 10th week of treatment. At the end of 9th week of treatment a nice and healthy wound margin was observed and reddish vascular marking all over the wound surface area was noted. At the end of 10th week of treatment the wound was assessed and the surround areas was checked for any sign of wound dehiscence, infection, vascularity of the wound as well as adjacent areas and was found up to mark. The patient was discharged. In addition to laser therapy and surgical intervention, the patient was adjacently also given the pneumatic bed support, catheterization, high protein diet, antibiotics (according to culture and sensitivity test), pain killer (Non-NSAID), pantoprazole and ranitidine, perkinil, aspirin $(75 \mathrm{mg})$, vitamin B-complex, anti-oxidant, vitamin D3, Iron, Folic acid and Zinc supplements, Calcium, Fresh blood transfusion.

Table 1: Treatment Schedule (Dose duration and wound parameter

\begin{tabular}{|c|c|c|c|c|c|c|c|}
\hline 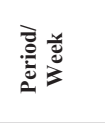 & 总 & 总芯 & 总 & $\sum_{i}^{D}$ & 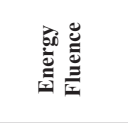 & $\vec{\Xi}$ & $\stackrel{\Xi}{\Xi}$ \\
\hline 1-2 week & 5/ week & $6.8 \mathrm{~cm}^{2}$ & $\begin{array}{l}\text { LED-660 nm } \\
\text { (Ga-Al-As) }\end{array}$ & Continuous & 6 joules $/ \mathrm{cm}^{2}$ & 2 & $\begin{array}{l}8 \text { joules/ } \\
\text { min. }\end{array}$ \\
\hline $3-5$ week & 3/ week & $5.7 \mathrm{~cm}^{2}$ & $\begin{array}{l}\text { LED-660 nm } \\
\text { (Ga-Al-As) }\end{array}$ & Continuous & 4 joules $/ \mathrm{cm}^{2}$ & 2 & $\begin{array}{l}8 \text { joules/ } \\
\text { min. }\end{array}$ \\
\hline 4-6 week & 3/ week & $4.4 \mathrm{~cm}^{2}$ & $\begin{array}{l}\text { LED-660 nm } \\
\text { (Ga-Al-As) }\end{array}$ & Continuous & 4 joules $/ \mathrm{cm}^{2}$ & 1 & $\begin{array}{l}8 \text { joules/ } \\
\text { min. }\end{array}$ \\
\hline $7-8$ week & 2/week & $2.2 \mathrm{~cm}^{2}$ & $\begin{array}{l}\text { LED-660 nm } \\
\text { (Ga-Al-As) }\end{array}$ & Continuous & 3 joules $/ \mathrm{cm}^{2}$ & 1 & $\begin{array}{l}8 \text { joules/ } \\
\text { min. }\end{array}$ \\
\hline 9-10 week & 2/ week & Closed & $\begin{array}{l}\text { LED-660 nm } \\
\text { (Ga-Al-As) }\end{array}$ & Continuous & 3 joules $/ \mathrm{cm}^{2}$ & 1 & $\begin{array}{l}8 \text { joules } \\
\text { min. }\end{array}$ \\
\hline
\end{tabular}

\section{Discussion}

In this case report potential changes in healing were observed after giving LLLT over time by using a human experimental wound model. Healing was measured in terms of wound contraction and changes in chromatic red and luminance ${ }^{31}$. Chromatic red is an indication of wound healing as a wound changes in color from dark red to pale pink over time ${ }^{32-36}$. Luminance refers to the homogeneity of a wound as the tissue heals and becomes more smooth and consistent $^{37-40}$.

Patient demonstrated a significant benefit of Ga-Al-As 660 laser for rapid healing of skin wound. The comparison between the laser and conventionally treated previously treated wounds of the same patient at about same size clearly highlighted that despite uniformity of host factors, local factors and systemic state, the wound healing process was stimulated on the laser exposed side ${ }^{41}$. Healing of wounds is an important problem faced by general and orthopedic surgeons. The possible biostimulatory role of laser light in wound healing is of recent interest ${ }^{42}$. Small sub destructive repetitive doses of laser light are claimed to be useful for trophic ulcers and indolent wounds ${ }^{43}$.

The proposed mechanisms of action include local leukocyte proliferation, neovascularization, fibroblastic proliferation and rapid epithelialization ${ }^{44-45}$. All these mechanisms possibly lead to more rapid closure of wounds and stronger scar formation. In an experimental study, wounds treated with Ga-Al-As 660 laser revealed significantly more granulation tissue. This study established the biostimulatory effects of low intensity laser radiation ${ }^{46}$. Many reports now indicate benefit to non healing wounds and trophic ulcers by low-intensity laser irradiation. Out of 351 patients thus treated, 236 showed complete epithelialization of the wound surface $^{47}$. A $44 \%$ increase in healthy granulation tissue was observed, $2 / 12$ ulcers healed completely while $27 \%$ revealed reduction in size of the remaining ulcers indicating considerable benefit ${ }^{48}$. Nussbaum et $\mathrm{a}^{47}$ in a study compared the effect of ultraviolet- $\mathrm{C}$ and laser for treatment of pressure 
ulcers in adults with spinal cord injury. They used 660-980 $\mathrm{nm}$ wave length light at an energy density of $4 \mathrm{~J} / \mathrm{cm} 2$. Weekly percentage changes in wound area were compared. The authors concluded exposure to UV-C decreased healing time and allowed faster return to rehabilitation programs. The UV-C light was better than the laser ${ }^{47}$. Another nonrandomized study of laser and UV lamp on chronic skin ulcers suggested that wounds which fail to respond to topical treatments benefit from either modality ${ }^{49}$. Evaluations of different approaches to wound healing are complicated by the large number of factors that influence wound healing. Although there are anecdotal reports of successful therapy, there are few well controlled studies. The use of lasers for healing wounds is becoming increasingly attractive to surgeons. A number of animal and in vitro studies ${ }^{48-50}$ has demonstrated that laser irradiation has a significant effect on components of tissue repair.

This study results efficacy of LLLT on wound healing in human model, and indicates that it can be a very important adjective tool /modality for chronic intractable wound management, and in any way it is not harmful to human being. In the past Laser/LED were shown to be effective in wound management but in different degrees, some of those applications showed significant improvement some less effective others no effect. Probably laser/ LED Irradiation parameters are vital for its biostimulative effects. Inference of those results summaries that irradiation parameters are of vital to laser therapy. We used an optimal dose of irradiance which proved to be most effective biostimulation on human application. Application and research of LLLT on cell responses of wounded skin fibroblasts demonstrate that correct energy density or fluency and number of exposures can stimulate cell responses of wounded fibroblast and promote cell migration and cell proliferation by stimulating mitochondrial activity and maintaining viability without causing additional stress or damage to wounded cells. Results indicate that the cumulative effect of lower doses determines the stimulatory effect, whereas multiple exposures at higher doses result in an inhibitory effect with more damage ${ }^{39}$.

Although various studies have extensively covered the effects of laser radiation on tissue, many unanswered questions remain. The mechanisms effectively responsible for cell mitotic activity has not been clarified yet, and there is no standardized ideal dose for stimulating tissue healing. Therefore, we noted that there is a need for research on the action and parameters of low-intensity laser use in cutaneous lesions during the different stages of repair, as an attempt to elucidate how this method acts at a cell level in healing processes. Elucidation of these issues will enable the establishment of criteria on the true benefits of laser therapy in diseases that need healing stimulation, minimizing healing time and the complications that may occur during the clinical progress of these wounds. In addition, experimental studies indicated that the LLLT may be an important therapeutic tool to stimulate wound healing in decubitus ulcer patients.

\section{Conclusion}

In conclusion, the present report highlights the possible utility of Galliium-Aluminium laser at 660 wavelengths is as effective as Helium-Neon laser as an adjunctive modality for wound healing in skin/general \& orthopedic practices.

\section{References}

1. Snyder RJ. Treatment of nonhealing ulcers with allografts. Clin Dermatol. 2005; 23:388-95

2. Sugrue ME, Carolan J, Leen EJ, Feeley TM, Moore DJ, Shanik GD. The use of infrared laser therapy in the treatment of venous ulceration. Ann Vasc Surg. 1990; 4:179-81

3. Chromey PA. The efficacy of carbon dioxide laser surgery for adjunct ulcer therapy. Clin Podiatr Med Surg. 1992; 9:709-19

4. Nussbaum EL, Zuylen JV, Baxter GD. Specification of treatment dosage in laser therapy: unreliable equipment and radiant power determination as confounding factors. Physiotherapy Can. 1999; 157-167

5. Rocha Jr. AM, de Oliveira RG, Farias RE, de Andrade LCR, Aarestrup FM. Modulation of fibroblast proliferation and inflammatory response by low-intensity laser therapy in tissue repair process. An Bras Dermatol. 2006; 81:150-6

6. Economic consequences of diabetes mellitus in the U.S in 1997. American Diabetes Association. Diabetes Care. 1998; 21:296-309

7. Pedrosa HC. Pé diabético: aspectos histopatológicos, tratamento e prevenção. Rev Bras Neurol Psiquiatr. 1997; 1:131-5

8. Ramos-e-Silva M, Ribeiro de Castro MC. New dressings, including tissue-engineered living skin. Clin Dermatol. 2002; 20:715-23

9. Sheridan RL, Thompkins RG. What's new in burns and metabolism? J Am Coll Surg. 2004; 198:243-63

10. Contran RS, Kumar V, Collins T. Robbins. Patologia estrutural e funcional. Rio de Janeiro: Guanabara Koogan; 2001. p. 44-100

11. Mandelbaum SH, Di Santis EP,Mandelbaum MHS.Cicatrização: conceitos atuais e recursos auxiliaries: parte I.An Bras Dermatol. 2003;78:393-408

12. Tanaka A, Hatoko M, Tada H, Iioka H, Niitsuma K, Miyagawa S. Expression of p53 family in scars. J Dermatol Sci. 2004; 34:17-24

13. Silva EC, Filho AH, Musskopf DE. Radiação laser. In: Rodrigues EM. Manual de recursos terapêuticos. Rio de Janeiro: Revinter; 1998. p. 17-35 14. KaruT, Pyatibrat L, Kalendo G. Irradiation with He-Ne laser increases ATP level in cells cultivated in vitro. J Photochem Photobiol 1995;27:219-23

15. Herrero C. Los efectos terapeuticos. Bol Sociedad Española Láser Médico Quirúrgico. 1988; 15:22-6

16. Bibikova A, Belkin V, Oron U. Enhancement of angiogenesis in regenerating gastrocnemius muscle of the toad (Bufo viridis) by lowenergy laser irradiation. Anat Embryol (Berl). 1994; 190:597-602

17. Mester AF, Mester A. Wound healing. Laser Ther. 1989; 1:7-15

18. Hopkins JT, McLoda TA, Seegmiller JG, Baxter GD. Low-level laser therapy facilites superficial wound healing in humans: a triple-blind, sham- controlled study. J Athl Train. 2004; 39:223-9

19. Catão MHCV. Os benefícios do laser de baixa intensidade na clínica odontológica na estomatologia. Rev Bras Patol Oral. 2004;3:214-8

20. Dallan LAO, Oliveira SA. Cirurgia de revascularização transmiocárdica a laser de CO2. Rev Bras Cir Cardiovasc. 2000; 15:89104

21. Gomez-Villamandos RJ, Santisteban Valenzuela JM, Ruiz Calatrava I, 
Gomez-Villamandos JC, Avila Jurado I. He-Ne laser therapy by fibroendoscopy in the mucosa of the equine upper airway. Lasers Surg Med. 1995; 16:184

22. Weis LC, Arieta A, Souza J, Guirro RRJ. Utilização do laser de baixa potência nas clínicas de fisioterapia de Piracicaba, SP. Fisioter Bras.2005; 6:124-9

23. Kolárová H, Ditrichová D, Wagner J. Penetration of the laser light into the skin in vitro. Lasers Surg Med. 1999; 24:231-5

24. Parizotto NA, Baranauskas V. Structural analysis of collagen fibrils after HeNe laser photostimulated regenerating rat tendon. In: 2o Congress World Association for Laser Therapy; Sep 2-5. Kansas City. Proceedings. Kansas City; 1998. p. 66

25. Gogia PP, Hurt BS,Zirn TT.Wound management with whirlpool and infrared cold laser treatment. A clinical report. Phys Ther. 1988; 68:1239-42 26. Lundeberg T, Malm M. Low-power HeNe laser treatment of venous leg ulcers. Ann Plast Surg. 1991; 27:537-9

27. Allendorf JD, Bessler M, Huang J, et al. Helium-neon laser irradiation at fluences of 1,2 , and $4 \mathrm{~J} / \mathrm{cm} 2$ failed to accelerate wound healing as assessed by wound contracture rate and tensile strength. Lasers Surg Med. 1997; 20:340-5

28. Lucas C, Criens-Poublon LJ, Cockrell CT, de Haan RJ. Wound healing in cell studies and animal model experiments by Low Level Laser Therapy; were clinical studies justified? a systematic review. Lasers Med Sci. 2002; 17:110-34

29. Moriyama Y, Moriyama EH, Blackmore K, Akens MK, Lilge L. In Vivo Study of the Inflammatory Modulating Effects of Low-level Laser Therapy on iNOS Expression Using Bioluminescence Imaging, Photochem Photobiol 2005;81: 1351-5

30. Schafer FQ, Buettner GR. Redox environment of the cell as viewed through the redox state of the glutathione disulfide/glutathione couple, Free Radic Biol Med 2001;30:1191-212

31. Liu H, Colavitti R, Rovira II, Finkel T. Redox-dependent transcriptional regulation, Circ Res 2005;97:967-74

32. Yang M, Nazhat NB, Jiang X, Kelsey SM, Blake DR, Newland AC, Morris CJ. Adriamycin stimulates proliferation of human lymphoblastic leukaemic cells via a mechanism of hydrogen peroxide (H2O2) production, Br J Haematol 1996;95: 339-44

33. Kirlin WG, Cai J, Thompson SA, Diaz D, Kavanagh TJ, Jones DP. Glutathione redox potential in response to differentiation and enzyme inducers, Free Radic Biol Med 1999;27:1208-18

34. Alaluf S, Muir-Howie H, Hu HL, Evans A, Green MR. Atmospheric oxygen accelerates the induction of a post-mitotic phenotype in human dermal fibroblasts: the key protective role of glutathione, Differentiation 2000;66:147-55
35. Karu T. Primary and secondary mechanisms of action of visible to near-IR radiation on cells, J Photochem Photobiol 1999; 49:1-17 36. Young S, Bolton P, Dyson M, Harvey W, Diamantopoulos C. Macrophage responsiveness to light therapy, Lasers Surg Med 1989;9: 497-505

37. Fujimaki Y, Shimoyama T, Liu Q, Umeda T, Nakaji S, Sugawara K. Low-level laser irradiation attenuates production of reactive oxygen species by human neutrophils, J Clin Laser Med Surg 2003;21:165-70

38. Chen YS, Hsu SF, Chiu CW, Lin JG, Chen CT, Yao CH. Effect of lowpower pulsed laser on peripheral nerve regeneration in rats, Microsurgery 2005;25:83-9

39. Miloro M, Halkias LE, Mallery S, Travers S, Rashid RG. Low-level laser effect on neural regeneration in Gore-Tex tubes, Oral Surg Oral Med Oral Pathol Oral Radiol Endod 2002;93:27-34

40. Gogoa PP, Margue RR. Effects of Hellium-Neon laser on wound healing. Osteomy Wound Manag 1992; 38: 33-41

41. Koshelev VN, Arkhangel AV, Glukhov El. Effect of low intensity carbon dioxide laser on reparative regeneration of experimental wounds. Byulleten Eksperimental noi Biologii Meditriny 1985; 99: 338-341

42. Kana JS, Hutschenreiter G, Haina D, Waidelich W. Effect of low power density laser radiation on healing of open skin wounds in rats. Arch Surg 1981; 116: 293- 295

43. Avevbakh MM, Sorkin MZ, Dobkin VG, Kosarev II, Ostapehenko EP. Effect of Helium- Neon laser on the healing of aseptic experimental wounds. EKSP Khir Anaesteziol 1976; 3: 56-61

44. Mester E, Spiry T, Szends B. Effect of laser rays on wounds healing. Bull Soc Int Chir 1973; 32:169-172

45. Bisht D, Gupta SC, Misra V, Mittal VP, Sharma P. Effect of low intensity laser radiation on healing of open skin wounds in rats. Indian J Med Res 1994; 100: 43- 46

46. Sugrue ME, Careolan J, Leen EJ, Feeley TM, Moore DJ, Shanik GD. The use of infrared laser therapy in the treatment of venous ulceration. Ann Vase Surg 1990; 179-181

47. Nussbaum E L, Biemann I, Mustard B. Comparison of ultrasound/ultraviolet-c and laser for treatment of pressure ulcers in patients with spinal cord injury. Physical Therapy 1994; 74: 812-823

48. Crous L, Malherbe C. Laser and ultraviolet light irradiation in the treatment of chronic ulcers. Physiotherapy 1988; 44: 73-77

49. Young S. Dyson M, Bottom P. Effect of light on Calcium uptake by macrophages. Presented at a Seminar on Laser Biomodulation at Guy's Hospital, London, 1991

50. El Sayed S, Dyson M. Comparison of the effect of multiwavelength light produced by a cluster of semiconductor diodes and of each individual diode on mast cell number and degranulation in intact and injured skin. Laser Surge Med 1990; 10: 559-568. 